\title{
APPLICATION OF HEALTH BELIEF MODEL ON THE PREDICTORS OF SCREENING FOR CERVICAL CANCER IN SURAKARTA, CENTRAL JAVA
}

\author{
Gabriela Advitri Febriani'), Setyo Sri Rahardjo²), Bhisma Murti') \\ 1)Masters Program in Public Health, Universitas Sebelas Maret \\ ${ }^{2)}$ Faculty of Medicine, Universitas Sebelas Maret
}

\begin{abstract}
Background: Research on Indonesian women that examine factors associated with uptaking regular Pap or Visual Inspection Acetic Acid (VIA) tests is lacking. The purpose of this study was to use the health belief model (HBM) as a framework to examine predictors of Pap or VIA testing.

Subjects and Method: An analytic cross-sectional study has been conducted at Permata Harapan Clinic and Budi Sehat Laboratory Clinic, Surakarta, Central Java. The data were collected from February to March 2018. A sample of 200 women was selected by random sampling, consisting of 74 women undertaking screening and 126 women not undertaking screening. The dependent variable was use of screening for cervical cancer. The independent variables were perceived susceptibility, seriousness, benefit, barrier, education, income, and social support. Data on screening were taken from medical record. Other variables were measured by questionnaire. The data were analyzed by path analysis.

Results: Perceived susceptibility $(b=2.20 ; 95 \% \mathrm{CI}=1.38$ to $3.02 ; \mathrm{p}<0.001$ ), seriousness $(b=1.24 ; 95 \% \mathrm{CI}=0.18$ to $2.30 ; \mathrm{p}=0.022)$, and benefit $(b=1.24 ; 95 \%$ $\mathrm{CI}=0.17$ to $2.30 ; \mathrm{p}=0.023$ ) were positive predictors of screening. Perceived barrier $(b=-1.03 ; 95 \% \mathrm{CI}=-1.83$ to $-0.23 ; \mathrm{p}=0.012)$ was a negative predictor of screening. Education, income, and social support were significant and indirect predictors of screening.

Conclusion: Perceived susceptibility, seriousness, and benefit are positive predictors of screening. Perceived barrier is a negative predictor of screening. Education, income, and social support are significant and indirect predictors of screening. Health belief model can be used to predict uptake of screening for cervical cancer.
\end{abstract}

Keywords: health belief model, screening, cervical cancer

\section{Correspondence:}

Gabriela Advitri Febriani. Masters Program in Public Health, Universitas Sebelas Maret. Jl. Ir. Sutami No. 36 A, 57126, Surakarta, Central Java.

Email: gabrielaadvitri8@gmail.com. Mobile: 085743809055. 